\title{
Bioreduction of $\alpha$-methyleneketones
}

\author{
Moacir de Mancilha, Roseli De Conti, Paulo J. S. Moran, and J. Augusto R. Rodrigues*
}

Universidade Estadual de Campinas, Instituto de Química, 13083-970 Campinas-SP, Brazil

E-mail:jaugusto@iqm.unicamp.br

\section{Dedicated to Prof. R. A. Abramovitch in honor of his $\mathbf{7 0}^{\text {th }}$ birthday \\ (received 01 May 01; accepted 09 Oct 01; published on the web 17 Oct 01)}

\begin{abstract}
Bioreduction of methyleneketones was carried out with Rhizopus arrhizus, Pseudomonas fluorescens and immobilized Saccharomyces cerevisae. The $\alpha$-substituted enones were enantioselectively reduced to saturated ketones with good to excellent ee, depending of microorganism. With the S. cerevisae good ee (12-93\%) was obtained while excellent ee (99\%) was achieved with $P$. fluorescens.
\end{abstract}

Keywords: Bioreduction, methyleneketones, acrylophenones

\section{Introduction}

The growing interest in asymmetric synthesis has promoted great developments in biotransformations in organic synthesis applied for the synthesis of chiral compounds. ${ }^{1}$ Baker's yeast has been widely used, mainly for the reduction of the carbonyl groups of pro-chiral ketones, producing alcohols with high enantiomeric purity. ${ }^{2}$ Reduction of a $\mathrm{C}=\mathrm{C}$ bond has also been achieved, although it is mostly frequently conjugated with a carbonyl group. ${ }^{3}$ Less attention has been paid to the bioreduction of $\alpha$-methyleneketones and most studies were carried out with baker's yeast. ${ }^{4}$ Chiral $\alpha$-methyleneketones are structural moieties in a large class of compounds, such as drugs and pheromones ${ }^{5}$ and, in many cases bioactivity is dependent upon the 
configuration of the $\alpha$-carbon. the. ${ }^{6}$ Herein we wish to report chemo- and enantioselective bioreduction studies of $\alpha$-methyleneketones using as catalyst Saccharomyces cerevisae (baker's yeast), Rhizopus arrhizus and Pseudomonas fluorescens. The $\alpha$-substituted enones are reduced to the saturated ketones with good to excellent ee, depending on the microorganisms.

\section{Results and Discussion}

Synthetic routes to $\alpha$-methylene carbonyl compounds have received considerable attention due the importance of this class of compounds as useful intermediates. ${ }^{7}$ A number of methods have been described and reviewed. ${ }^{8}$ We have tested different methods for a direct methylene transfer; ${ }^{9}$ the most successful, efficient and general method was the direct Mannich $\alpha$-methylenation introduced by Kim. ${ }^{10}$ Treatment of the appropriate ketone with $37 \%$ aqueous formaldehyde solution in the presence of morpholine in refluxing acetic acid directly furnished the desired unsaturated ketone in good yield (see Table 1).

Baker's yeast reduction of 2-methyl-1-phenylprop-2-en-1-one 2a was fast and gave isopropyl phenyl ketone 3a in reasonable yields. In order to facilitate the isolation of the product from the broth we employed yeast immobilized (IMBY) onto montmorillonite K10. ${ }^{11}$ Using short periods $(6 \mathrm{~h})$ of incubation only the ketone 3a (nearly 50\% yield) and the starting acrylophenone 2a were isolated. After $12 \mathrm{~h}$ of reaction, 3a was isolated in $76 \%$ yield and traces of the alcohol 3-methyl-1-phenyl-2-propanol. With long periods, reduction of the ketone to the alcohol increased very little. It is known that aryl methyl ketones are reduced to $(S)$-alcohols in modest yield with approximately $70 \%$ ee. ${ }^{12}$ Treatment of the acrylophenone $\mathbf{2 b}$ with IMBY gave, after 12 h, a 67\% yield of (2R)-1-phenyl-2-methylbutan-1-one $3 \mathbf{b}$ in 93\% ee. The absolute configuration was determined comparing the $[\alpha] \mathrm{D}-24.0$ with the published value. ${ }^{13}$ Reduction of methyl 3-benzoylbut-3-enoate 2c with IMBY for $12 \mathrm{~h}$ gave a good yield (59\%) of methyl (-)(3S)-3-benzoyl-3-methylbutanoate $3 \mathbf{c}$ with poor enantioselective $12 \%$ ee. ${ }^{14}$ A satisfactory result was obtained with $2 \mathbf{e}$ which gave $3 \mathbf{e}$ in $65 \%$ yield with $85 \%$ ee. Attempts to reduce acid $\mathbf{2 d}$ were not successful since products were not isolated from the reaction with IMBY.

In order to find other active microorganisms with the above substrates we chose the fungus Rhizopus arrhizus and the bacterium Pseudomonas fluorescens. The biotransformations were conducted with a resting cell mass/substrate ratio of 30/1 in a phosphate buffer solution (PBS) at $\mathrm{pH} 7$ at $30{ }^{0} \mathrm{C}$ and $110 \mathrm{rpm}$. In Table 2 we present the results. Reduction of substrates 2a-e with $R$. arrhizus gave the same reduction products with yields similar to those obtained with IMBY but the ee are poor. Better results were achieved with $P$. fluorescens, giving higher yields and 
enantioselectivities than with IMBY and $R$. arrhizus. The enzyme enoate reductase present in $P$. fluorescens gave, with all substrates, ee not less than $99 \%$ for the reduction of the $\mathrm{C}=\mathrm{C}$.

We have commented above that aryl alkyl ketones are reduced by baker's yeast in low yields although the study of the reduction of $\gamma$-ketoesters $1 \mathrm{c}$ and $1 \mathrm{e}$ was not systematically consummated. In contrast, it is well known that $\alpha$ - and $\beta$-ketoesters are very suitable substrats for biocatalysts. $^{2 \mathrm{~b}-\mathrm{c}}$ The ketoester 1e was not metabolized by IMBY since the $p$-methoxy group is a strong electron donor that inactives the substrate. ${ }^{15}$ Reaction of the $\gamma$-ketoester 1c with IMBY gave, after several days, two main compounds, lactone 4 and $\gamma$-ketoacid 1d. Considering that the amount of $\mathbf{1 d}$ is dependent on reaction time, we carried out the reaction of $\mathbf{1 d}$ as substrate with IMBY. After $20 \mathrm{~h}$ the (-)-(S)-5-phenyl-4,5-dihydrofuran-2(3H)-one 4 was isolated in $70 \%$ yield and $94 \%$ ee. This lactone was obtained in low yield by bioreduction of ethyl 3benzoylpropionate with free BY after 7 days of incubation.16 Further studies of bioreduction of $\gamma$-ketoacids are in development and will be published soon.

In summary, IMBY is a good biocatalyst for enantioselective reduction of the $\mathrm{C}=\mathrm{C}$ bond of $\alpha$-methyleneketones to saturated ketones. Excellent ee was obtained with the bacterium $P$. fluoresncens.

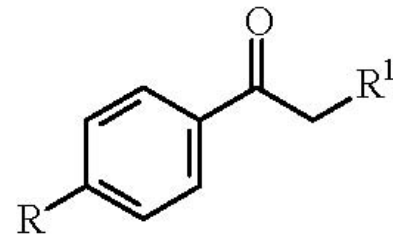

1

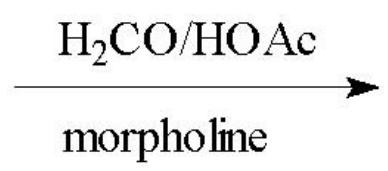

morpholine<smiles>[R]C(=C)C(=O)c1ccc([R])cc1</smiles>

2

a. $\mathrm{R}=\mathrm{H} ; \mathrm{R}^{1}=\mathrm{CH}_{3}$ d. $\mathrm{R}=\mathrm{H} ; \mathrm{R}^{1}=\mathrm{CH}_{2} \mathrm{CO}_{2} \mathrm{H}$

b. $\mathrm{R}=\mathrm{H} ; \mathrm{R}^{1}=\mathrm{CH}_{2} \mathrm{CH}_{3}$ e. $\mathrm{R}=\mathrm{OCH}_{3} ; \mathrm{R}^{1}=\mathrm{CH}_{2} \mathrm{CO}_{2} \mathrm{CH}_{3}$

c. $\mathrm{R}=\mathrm{H} ; \mathrm{R}^{1}=\mathrm{CH}_{2} \mathrm{CO}_{2} \mathrm{CH}_{3}$<smiles>[R]C(=C)C(=O)c1ccc([R])cc1</smiles>

2a-e

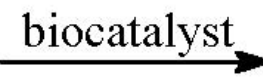<smiles>[R]c1ccc(C(=O)[C@H]([R])C)cc1</smiles>

3a-e 
<smiles>O=C(O)CCC(=O)c1ccccc1</smiles>

$1 d$
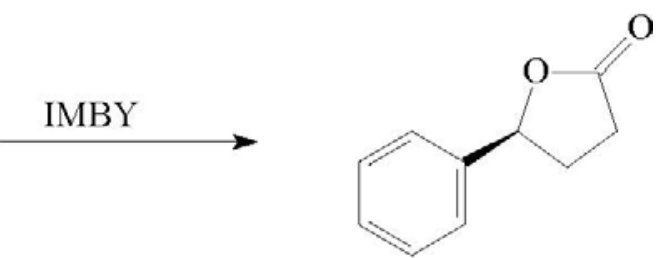

4

Table 1. $\alpha$-Methylenation of representative ketones ${ }^{\mathrm{a}}$

\begin{tabular}{cccccc}
\hline Entry & Substrate & Product & Time, h & Yield (\%) & Ref. $^{\text {b }}$ \\
\hline 1 & 1a & $(\mathbf{2 a})^{\mathrm{a}}$ & 8 & 82 & 17 \\
2 & 1b & $\mathbf{2 b}$ & 12 & 84 & 18 \\
3 & 1c & $\mathbf{2 c}$ & 6 & 91 & 19 \\
4 & 1d & $\mathbf{2 d}$ & 6 & 62 & --- \\
5 & 1e & $\mathbf{2 e}$ & 6 & 71 & --- \\
\hline
\end{tabular}

a. All Products exhibited satisfactory spectral properties $\left({ }^{1} \mathrm{H}-\mathrm{NMR}{ }^{13} \mathrm{C}-\mathrm{NMR}, \mathrm{IR}, \mathrm{MS}\right)$ fully in accord with known or expected values.

b. References for the known compounds.

Table 2. Reduction of $\alpha$-methyleneketones with microorganisms

\begin{tabular}{ccccccc}
\hline Entry & Product & Biocatalyst & Time h & Yield \% & ee & Ref $^{\mathrm{a}}$. \\
\hline 1 & 3a & IMBY & 12 & 76 & --- & 20 \\
& & R. arryzus & 24 & 65 & --- & \\
& & P.fluorecens & 24 & 90 & --- & 13 \\
2 & 3b & IMBY & 12 & 67 & 93 & \\
& & R. arryzus & 24 & 76 & 43 & 14 \\
& & P.fluorecens & 24 & 79 & 99 & \\
3 & 3c & IMBY & 12 & 59 & 12 & \\
& & R. arryzus & 24 & 69 & 25 & \\
& & P.fluorecens & 24 & 73 & 99 & \\
4 & 3d & IMBY & 17 & & 85 & \\
5 & 3e & IMBY & 17 & 65 & 35 & \\
& & R. arryzus & 24 & 56 & 99 & \\
& & P.fluorecens & 24 & 69 & & \\
\end{tabular}

a. References for the known compounds 


\section{Experimental Section}

General Procedures. The IR spectra were recorded on a Hartmann \& Braun BOMEM MB SERIES spectrometer. The ${ }^{1} \mathrm{H}-\mathrm{NMR}$ and ${ }^{13} \mathrm{C}-\mathrm{NMR}$ were recorded on a VARIAN-INOVA spectrometer. Mass spectra were recorded on a SHIMADZU GC/MS - QP 5000 gas chromatograph/mass spectrometer and with helium as carrier gas. A 30m X $0.25 \mathrm{~mm}$ I.D. SUPELCO SIMPLICITYTM capillary column was used and the chiral column employed in the determination of enantiomeric excess (ee) was a $25 \mathrm{~m}$ X $0.25 \mathrm{~mm}$ I.D. CHIRASIL-DEX from CHROMPACK. An injector temperature of $230{ }^{\circ} \mathrm{C}$ and a detector temperature of $280{ }^{0} \mathrm{C}$, with the column at $50{ }^{0} \mathrm{C}$ for $3 \mathrm{~min}$; then using a rate of $200 \mathrm{C} / \mathrm{min}$. up to $280{ }^{0} \mathrm{C}$, with a pressure of $100 \mathrm{kPa}$ and gas flow of $80 \mathrm{ml} / \mathrm{min}$. Optical rotations were measured using a Carl Weiss POLAMAT A polarimeter. CD spectra were recorded on a JASCO-J720 spectropolarimeter at $25{ }^{0} \mathrm{C}$. Preparative column chromatography was carried out using silica gel 60 (Merck). Commercially available chemicals and solvents were used without further purification.

\section{$\alpha$-Methylenenation of benzophenones and $\boldsymbol{\gamma}$-ketoesters and acids.}

The mixture of a ketone $(10 \mathrm{mmol})$ and morpholine $(5 \mathrm{mmol})$ in $20 \mathrm{~mL}$ of glacial acetic acid was heated under reflux. To this refluxing mixture a $37 \%$ aqueous formaldehyde solution $(5 \mathrm{~mL})$ was added dropwise over several hours (6-24 h). After completion of the reaction, acetic acid was stripped off under reduced pressure and the residue was diluted with ethyl acetate. The organic layer was washed successively with $10 \%$ aqueous hydrochloric acid, saturated sodium bicarbonate solution, water and brine, and then dried over anhydrous magnesium sulfate. The solvent was evaporated. The crude oil was purified by silica gel column chromatography.

Methyl 3-benzoylbut-3-enoate (2c). ${ }^{14}$

Oil, 91\% yield; IR (film) v 2955, 1740, 1687, 1659, 1599, 1449, $1203 \mathrm{~cm}^{-1}$; ${ }^{1} \mathrm{H}-\mathrm{NMR}(300 \mathrm{MHz}$, $\left.\mathrm{CDCl}_{3}\right) \delta 3.56(2 \mathrm{H}, \mathrm{s}), 3.69(3 \mathrm{H}, \mathrm{s}), 5.79(1 \mathrm{H}, \mathrm{s}), 6.00(1 \mathrm{H}, \mathrm{s}), 7.45(2 \mathrm{H}, \mathrm{t}, J=7.3), 7.53(1 \mathrm{H}, \mathrm{t}, J$ $=7.0), 7.79(2 \mathrm{H}, \mathrm{d}, J=7.0) .{ }^{13} \mathrm{C}-\mathrm{NMR}\left(75 \mathrm{MHz}, \mathrm{CDCl}_{3}\right) \delta 37.83,52.02,128.19,129.65,132.32$, 137.19, 141.18, 171.41, 196.99; MS m/e 204(M+1 5), 172(14), 145(8), 117(5), 105(100), 77(61), 59(8). Anal. Calcd for $\mathrm{C}_{12} \mathrm{H}_{12} \mathrm{O}_{3}$ : C, 70.57; H, 5.92. Found: C, 70.53; H, 6.02. 
3-Benzoylbut-3-enoic acid (2d).

Pale yellow oil, 62\% yield; IR (film) v 3062, 1712, 1657, 1597, 1449, $1233 \mathrm{~cm}^{-1}$; ${ }^{1} \mathrm{H}-\mathrm{NMR}(300$ $\left.\mathrm{MHz} \mathrm{CDCl}_{3}\right) \delta 3.56(2 \mathrm{H}, \mathrm{s}), 5.82(1 \mathrm{H}, \mathrm{s}), 6.04(1 \mathrm{H}, \mathrm{s}), 7.27(1 \mathrm{H}, \mathrm{s}), 7.44(2 \mathrm{H}, \mathrm{t}, J=7.7), 7.54$ $(1 \mathrm{H}, \mathrm{t}, J=6.2), 7.78(2 \mathrm{H}, \mathrm{d}, J=5.1) ;{ }^{13} \mathrm{C}-\mathrm{NMR}\left(75 \mathrm{MHz}, \mathrm{CDCl}_{3}\right) \delta 37.89,58.41,128.22$, 129.70, 129.75, 132.45, 136.98, 140,63, 175.73, 197.18; MS m/e 190(M+, 3), 147(3), 131(3), 105(100), 77(48), 51(26). Anal. Calcd for $\mathrm{C}_{11} \mathrm{H}_{10} \mathrm{O}_{3}$ : C, 69.46; H, 5.30. Found: C, 69.40; H, 5.34.

Methyl 3-(4-methoxybenzoyl)but-3-enoate (2e). Pale oil, 71\% yield; IR (film) v 2954, 2925, 1736, 1650, 1602, 1461, 1257, $1160 \mathrm{~cm}^{-1} ;{ }^{1} \mathrm{H}-\mathrm{NMR}\left(300 \mathrm{MHz}, \mathrm{CDCl}_{3}\right) \delta 3.55(2 \mathrm{H}, \mathrm{s}), 3,67(3 \mathrm{H}$, s), $3.87(3 \mathrm{H}, \mathrm{s}), 5.72(1 \mathrm{H}, \mathrm{s}), 5.91(1 \mathrm{H}, \mathrm{s}), 6.94(2 \mathrm{H}, \mathrm{d}, J=7.0), 7.85(2 \mathrm{H}, \mathrm{d}, J=79.2)$; ${ }^{13} \mathrm{C}-\mathrm{NMR}$ $\left(75 \mathrm{MHz}, \mathrm{CDCl}_{3}\right) \delta 38.33,52,11,55,57,113,74,127.30,132.41,141,54 ; 163.55,171.80,196.05$; MS m/e 234 (M+15), 203 (12), 175(11), 135(100), 107(33), 92(52), 77(85), 64(52), 50.28. Anal. Calcd. for $\mathrm{C}_{13} \mathrm{H}_{14} \mathrm{O}_{4}$ : C, 66.67; H, 5.98. Found: C, 66.35; H, 6.04.

Immobilization of baker's yeast. The immobilization of the yeast was obtained by adding fresh baker's yeast $(20 \mathrm{~g})$ to a suspension of montmorillonite $(20 \mathrm{~g})$ in water at $30{ }^{0} \mathrm{C}$ and then gently shaking the resulting suspension for $2 \mathrm{~h}$. After vacuum filtration, the immobilized baker's yeast (IMBY) was kept in a refrigerator.

\section{General procedure for the bioreductions with IMBY}

To a water suspension $(100 \mathrm{~mL})$ of IMBY was added commercial sugar $(10 \mathrm{~g})$ and $\mathrm{CaCl}_{2}(1.5 \mathrm{~g})$ under mechanic stirring at $30{ }^{0} \mathrm{C}$. After $30 \mathrm{~min}$ was added $1 \mathrm{mmol}$ of substrate dissolved in ethanol $(1 \mathrm{~mL})$. At the end of the reaction (determined by extraction of $1 \mathrm{~mL}$ samples with ethyl acetate and analysis in a CG/MS) ethyl acetate $(50 \mathrm{~mL})$ was added and the mixture was stirred for a further $1 \mathrm{~h}$ at $30{ }^{\circ} \mathrm{C}$. The reaction mixture was filtered under reduced pressure, the medium was extracted with ethyl acetate $(3 \times 20 \mathrm{~mL})$, the organic layer was dried over magnesium sulphate and filtered through a celite column. The solvent was evaporated under reduced pressure and the residue was purified on chromatographic plates and eluted with ethyl acetate:hexane (1:10). The purified product was dissolved in ethyl acetate $(10 \mathrm{mg} / \mathrm{ml})$ and analyzed by GC/MS.

\section{General procedure for the bioreductions with Rhizopus arrhizus and Pseudomonas fluorescens}

The microorganisms were reactivated in nutrient broth (NB-nutrient broth-Difco) $(50 \mathrm{~mL})$ for 24 $\mathrm{h}$ at $30{ }^{0} \mathrm{C}$. The cells were transfereed to an erlenmeyer $(2 \mathrm{~L})$ in $\mathrm{NB}(1 \mathrm{~L})$ and the 
microorganisms were incubated in a shaker at $100 \mathrm{rpm}$ and $30{ }^{0} \mathrm{C}$ for $17 \mathrm{~h}$. After that, the cells were centrifuged for $30 \mathrm{~min}$. at $300 \mathrm{rpm}$ and then transferred to erlenmeyers $(250 \mathrm{~mL})$ containing pH 7 PBS. (100 mL). The substrates $(50 \mathrm{mg})$ were dissolved in ethanol $(1 \mathrm{~mL})$ and added to the cell medium in a cell/substrate ratio of $30: 1$. The mixture was incubated at $30{ }^{0} \mathrm{C}$ and $100 \mathrm{rpm}$ for $48 \mathrm{~h}$. The reaction mixture was then extracted with ethyl acetate $(3 \mathrm{x} 20 \mathrm{~mL})$, the organic layer dried over magnesium sulphate and filtered through a celite column. The solvent was evaporated under reduced pressure and the residue purified on chromatographic plates and eluted with ethyl acetate:hexane (1:10). The purified product was dissolved in ethyl acetate $(10 \mathrm{mg} / \mathrm{ml})$ and analyzed by GC/MS.

Methyl (-)-4-phenyl-3-methyl-4-oxo-butanoate (3c). Pale yellow oil, 73\% yield, 99\% ee; IR $\left(\right.$ film) $v 2953,2923,1738,1687,1597,1464,1347,1174 \mathrm{~cm}^{-1} ;{ }^{1} \mathrm{H}-\mathrm{NMR}\left(300 \mathrm{MHz}, \mathrm{CDCl}_{3}\right) \delta$ $0.99(3 \mathrm{H}, \mathrm{d}, J=7.0), 2.35-2.37(1 \mathrm{H}, \mathrm{m}),, 2.97(2 \mathrm{H}, \mathrm{dd}, J=8.0), 3.65(3 \mathrm{H}, \mathrm{s}), 7.48(2 \mathrm{H}, \mathrm{t}, J=$ 7.7), 7.59 (1H, t, $J=7.1), 7.99$ (2H, d, $J=7.0)$; MS m/e 206( $\left.\mathrm{M}^{+}, 2\right), 175(4), 132(2), 105(100)$, 77(37), 51(17). $[\alpha]^{25}$ D $-6.0\left(\mathrm{c} 0.01, \mathrm{CHCl}_{3}\right)$.

Methyl (-)-4-(4-metoxyphenyl)-3-methyl-4-oxobutanoate (3e). Pale yellow oil, 69\% yield, $99 \%$ ee; IR (film) v 2927, 2853, 1738, 1679, 1600, 1461, 1379, 1244, $1170 \mathrm{~cm}^{-1}$. ${ }^{1} \mathrm{H}-\mathrm{NMR}$ (300 $\left.\mathrm{MHz}, \mathrm{CDCl}_{3}\right) \delta 0.87(1 \mathrm{H}, \mathrm{d}, J=7.0), 2.38-2.42(1 \mathrm{H}, \mathrm{m}), 2.96(2 \mathrm{H}, \mathrm{dd}, J=7.9), 3.65(3 \mathrm{H}, \mathrm{s})$, $3.88(3 \mathrm{H}, \mathrm{s}), 6.95(2 \mathrm{H}, \mathrm{d}, J=8.8), 7.98$ (2H, d, $J=9.2)$; MS $m / e$ 236(M $\left.\mathrm{M}^{+}, 2\right), 205(3), 135(100)$, 107(7), 92(9), 77(14). [ $\alpha]_{\mathrm{D}}^{25}-15\left(\mathrm{c} 0.55, \mathrm{CHCl}_{3}\right)$. HRMS calcd. for $\mathrm{C}_{13} \mathrm{H}_{16} \mathrm{O}_{4}$ : 236,2637; found $\mathrm{m} / \mathrm{z} 236,2629\left(\mathrm{M}^{+}\right)$.

\section{Acknowledgements}

The authors acknowledge and are grateful for grants from FAPESP (Processo 1998/16181-2) and a scholarship from CNPq for M. de M.

\section{References}

1. (a) Roberts, S. M. J. Chem. Soc., Perkin Trans.1 2000, 611.(b) Pereira, R. S. Crit. Rev. Biotechnol. 1988, 18, 25. (c) Roberts, S. M.; Turner, N. J.; Willets, A. J.; Turner, M. K. Introduction to Biocatalysis Using Enzymes and Micro-organisms; Cambridge University Press: New York, 1995. (d) Faber, K. Biotransformations in Organic Chemistry, $2^{\text {nd }}$ Edn; 
Springer: Berlin, 1995. (d) Duran, N.; De Conti, R.; Rodrigues, J. A.R. Bol. Soc. Chil. Quim. 2000, 45, 109.

2. (a) Kreutz, O. C.; Segura, R. C. M.; Rodrigues, J. A. R.; Moran, P. J. S. Tetrahedron Asymm. 2000, 11, 2107. (b) Czuk, R.; Glänzer, B. I. Chem. Rev. 1991, 91, 49. (c) Servi, S. Synthesis 1990, 1. (d) Kayser, M. M.; Mihovilovic, M. D.; Kearns, J.; Feicht, A.; Stewart, J. D. J. Org. Chem. 1999, 64, 6603. (e) Dao, D. H.; Okamura, M.; Akasaka, T.; Kawai, Y.; Hida, K.; Ohno, A. Tetrahedron Asymm 1998, 9, 2725.

3. D’Arrigo, P. D.; Pedrocchi, G.; Servi, S. Adv. Appl. Microbiol. 1997, 44, 81.

4. (a) Utaka, M.; Onoue, S.; Takeda, A. Chem. Lett. 1987, 971. (b) Sato, T.; Hanayama, K.; Fujisawa, T. Tetrahedron Lett. 1988, 29, 2197. (c) Sakai, T.; Matsumoto, S.; Hidaka, S.; Imajo, N.; Tsuboi, S.; Utaka, M. Bull. Chem. Soc. Jpn. 1991, 64, 3473. (d) Ferraboshi, P.; Reza-Elahi, S.; Verza, E.; Santaniello Tetrahedron Asymm. 1999, 10, 2639. (e) Siqueira Filho, E. P.; Rodrigues, J. A. R.; Moran, P. J. S. J. Mol. Catal. B: Enzymatic 2001, 618, 1.

5. (a) Mori, K.; Harashima, S. Tetrahedron Lett. 1991, 32, 5995. (b) Cywin, C. L.; Kallmerten, J. J. Nat. Prod. 1991, 54, 1664. (c) Shimizu, I.; Hayashi, K.; Ide, N.; Oshima, M. Tetrahedron 1991, 47, 2992.

6. (a) Tatsuta, K.; Masuda, N.; Nishida, H. Tetrahderon Lett. 1998, 39, 83. (b) Chida, N.; Yoshinaga, M.; Tobe, T.; Ogawa, S. Chem. Commun. 1997, 1043. (c) Nakajima, N.; Ubukata, M.; Yonemitsu, O. Heterocycles 1997, 46, 105.

7. Tye, H. J. Chem. Soc., Perkin Trans 1 2000, 275, and references there in.

8. For a review see Tramontini, M.; Angiolini, L. Mannich Bases, Chemistry and Uses; CRC Press: Boca Raton, 1994.

9. Rodrigues, J. A. R.; Siqueira-Filho, E. P.; Mancilha. M. D.; Moran, P. J. S. Synth. Commun. in press.

10. Kim, M. Y.; Lim, G. J.; Lim, J. I.; Kim, D. S.; Kim, I. Y.; Yang, J. S. Heterocycles 1997, 45, 2041.

11. Sorrilha, A. E. P. M.; Marques, M.; Joekes, I.; Moran, P. J. S.; Rodrigues, J. A. R. Biorg. Med. Chem. Lett. 1992, 2, 191.

12. Nakamura, K.; Ushio, K. Oka, S.; Ohno, A. Tetrahedron Lett. 1984, 25, 3979.

13. Oppolzer, W.; Darcel, C.; Rochet, P.; Rosset, S.; Brabander, J. D. Helv. Chim. Acta 1997, $80,1319$.

14. Blanco, L.; Rousseau, G.; Barnier, J. -P.; Guibé-Jampel, E. Tetrahedron Asymm. 1993, 4, 783.

15. Mitteilung, K.; Eichberger, G.; Faber, K.; Griengl, H. Monatsch. Chem. 1985, 116, 1233.

16. Manzocchi, A.; Casati, R.; Fiecchi, A.; Santaniello, E. J.; J. Chem. Soc., Perkin Trans 1 1987, 2753. 
17. Nájera, C.; Sansano, J. M. Tetrahedron 1990, 46, 3993.

18. Suzuki, T.; Ohwada, T.; Shudo, K. J. Am. Chem. Soc. 1997, 119, 6774.

19. Paterson, I. Tetrahedron 1988, 44, 4207.

20. Kissman, H. M.; Williams, J. W. J. Am. Chem . Soc. 1950, 72, 5323. 